DC 81'372

\title{
LANGUAGE AND THOUGHT
}

\author{
I. O. Gaidenko \\ Kyiv, National Technical University of Ukraine \\ "Kyiv Polytechnic Institute" \\ gaydenko.julia@ukr.net
}

The article is aimed at the problem of language-thought interrelation which has always been of great interest to philosophers and linguists as the former is inconceivable without the latter; thus, language and thought are inseparable. Although the question of language-thought interconnection has been studied by many linguists, there is no generally accepted approach to the distinction of their interdependence and convergence. One approach to the problem, for instance, relies on regarding "language as thought and thought as language" (M. Müller), the other approach, which the article is focused on, consists in underlying their inequality even though they form organic unity (A. Potebnya). Scientific works of distinguished linguists about thought objectification have been investigated. The issues of language-experience and language-culture interrelation as well as their correspondence to the subject of the article have been analyzed. Relation of the first type is of primary significance since experience is fundamental to formation of knowledge and, therefore, culture as well as words that constitute language classes. Being component part of a specific language class each word possesses the meaning somehow connected with the type of experience the class describes; the name of the class is also general and applicable to each of its constituents. Accumulated knowledge and experience are shared by means of words, i.e. objectified in language units. Full objectification is only possible when words are combined together into meaningfully complete patterns, which makes language a communication tool. As communication may be of verbal and non-verbal forms, it cannot equate with language; however, human language and communication share common properties which are described by the article.

Key words: language, thought, experience, idea, communication, communication tool.

Introduction. Language is the most distinctive and universal means of human communication used to represent phenomena of objective reality and external world in human minds. The representational nature of language is the result of thorough historical selection from the whole bunch of language means which testify to the depth of human cognitive activity, evolution of thinking, social order and culture.

Evolutionary nature of language has always been strongly emphasized by linguists. For instance, in the book "Language : Its Nature, Development and Origin" O. Jespersen wrote: “... a language or a word is no longer taken as something given once for all, but as a result of previous development and at the same time as the starting-point for subsequent development" [5, p.7].

Being a product of historical and evolutionary processes, language, through accumulation and dissemination of knowledge, and skills, becomes constitutive historical heritage inseparable from its speakers, their consciousness. The relationship between a human and language may be represented as the indivisible chain: 'thought - language - communication' or 'language - thought - communication" which component parts bear strong relations of interdependence and convergence. Relationships between links of the abovementioned chain have always been of great interest to philosophers and linguists.

The aim of the article is to analyze approaches to the distinction of language and thought as well as the relation of experience and culture to the article's subject matter; identify the role of language means and communication in thought objectification process.

To the problem of language and thought. The question of language-thought interrelation was first brought up by philosophers of Ancient Greece who used the 
term 'logos' to unify categories of being (universe), thinking (concept, reason, sense) and language (speech, language, statement). This issue also received a lot of consideration in the book 'Science of Thought' by M. Müller according to whom: "Language is thought and thought is language", "Language and intellect are identical" [7, pp.11-18].

The problem of interrelation between language and thought was not ignored by A. Potebnya, a distinguished philosopher and linguist of the $19^{\text {th }}$ century, who unlike M. Müller believed that spheres of language and thought do not coincide. He was strongly convinced that thought and language cannot be equal in status although they form organic unity.

As a result of his analysis of the relationship between thought and word A. Potebnya concluded that: "Language is not a means of expressing an already formulated thought but a means of creating it...It is not a reflection of an established world outlook but the activity which leads to its establishment. In order to become aware of his emotional states, to apprehend his external perceptions, man has to objectify each of them in a word and to relate this word to other words" [7, p.19]. Despite admitting the fact that some basic and simple generalizations may be possible without words, the philosopher considers the word, a combination of meaning and sound, to be a basic means used to convey the speaker's thoughts.

The idea about inequality of language and thought formulated by the philosopher is widely supported by modern scientists. Ida Kurcz, for instance, confirms that we cannot identify human thought with language because there exist many forms of nonlinguistic, imagelike thoughts in adults as well as in pre-linguistic children" [6, p.5]. Although practical communication problems may be overcome by pre-verbal children and thoughts may be expressed non-verbally, speech that serves as an articulate language actuation of ideas may change them fundamentally.

Language representation of ideas and thoughts. Language is an instrument for material objectification of individual abstract ideas. However, once it is formulated and uttered (language verbal means have been used to objectify it) the idea goes beyond the boundaries of an individual thought and is transformed into an element of public domain. Thus, to 'materialize' ideas one should make use of words as basic language means common to a particular culture.

A. Potebnya said, after A. von Humboldt, that: "We are confined within the boundaries of our language and we can only step out of it by stepping into another language; this means that we are forced to use the heritage of the past embodied in the language of our culture" [8, p.249]. This fact provides for the establishment of language as non-optional, culturally and historically justified instrument used to fully and comprehensively actualize ideas existing in the individual's mind. Therefore, thinking "is dependent upon concepts which are tied to language" [8, p.250].

Customary use of language and its units is also outlined in works of $\mathrm{O}$. Jespersen who considering the problem of language equates the use of words in communication process with a habit: "The only unimpeachable definition of a word is that it is a human habit, an habitual act on the part of one human individual which has, or may have, the effect of evoking some idea in the mind of another individual" [5, pp.7-8].

L. Bloomfield, who is widely known as a founder of American structuralism, described language as a constantly changing unity whose units are dual representations of human cognitive process that relate sounds to meanings, though the relation may be vague: "The change of language in time is of interest in the present connection because its phases again illustrate the absence of any conservative relation between sound and sense" [1, p.16]. In his scientific work the linguist puts specific attention to accumulative nature of the word used as an instrument of 
knowledge preservation and changes it may undergo in course of time. L. Bloomfield reviews language as opposed to gestures and associative character of the first; he admits that associative relations of type 'experience - word' may deviate and become vague making bonds between the word's lexical meaning (semantics) and experience (objective reality) nihilate.

Associative relations as underlying relations between words in the system of language were also addressed by A. Meillet for whom the word is association of meaning with a sound complex the use of which is defined grammatically [9, p.151]. Associative and grammatical relations between units within language structure are of great importance as the former relate the language to external world while the latter standardize the language use and relate objective phenomena expressed with the help of words to grammatical categories.

Grammatical categories characteristic of each particular word class are one of the means that objectify human ideas and thoughts; they are used to generalize meaning of a particular word by referring it to the whole class of language units, e.g. common to all verbs is grammatical meaning of procedurality etc. Thus, each uttered word is automatically identified with the word class already existing in language which makes it possible 'to connect one's own special ideas with the existing ideas' [8, p.250]. However, language is not only dictionary, but also a system of grammatical rules that helps combine its component parts into sentences. It is impossible to combine language elements into meaningful units without making them grammatically relative to each other. Therefore, language is a combination of grammatically relevant elements whose primary purpose is to serve as means of conveying thoughts.

Language and communication. Linguistics treats language as a tool of thought (cognition) and a tool of communication. E. Sapir says that language is purely human and non-instinctive method of community ideas, emotions, and desire by means of a system of voluntary produced symbols [3, p.4].

Regarding language as a conventional and generally accepted communication tool, O. Jespersen points out that to one of its most distinctive features belongs functionality: "A language is nothing but a function of certain living human beings. Language is purposeful activity and we should never lose sight of the speaking individuals and of their purpose in acting in this particular way" [5, p.7].

Being intrinsic to humans, language is not and cannot be identical with communication, for the last may encompass different nonverbal forms; however, human language and communication may share common properties as the former is an instrument of the latter. Specific language properties distinguishing it from other human and animal communication systems were duly formulated and described in scientific works of many well-known philosophers and linguists (Aristotle, L. Bloomfield, L. Das, C. Hockett, Plato, F. de Saussure etc.).

According to L. Das properties common to language and communication are:

1) Displacement: Capacity to produce messages that can refer to past and future time, and to other locations [3, p.5].

This property of language was first outlined in the work 'The Origin of Speech" by the remarkable structuralist C. Hockett [4], who introduced the approach of differentiating between human and animal communication systems based on 13 design-features of language as purely human communication tool. Displacement is an obvious, but deterministic language property as no other human or animal system enables people to talk about every possible place in present, past or future. Thus, human communication is not confined to a particular time or location. 
Displacement is one of multiple communication properties which reflect language-thought interrelation as language is a means used to materialize the results of human thinking processes (concepts), which are not limited by a communication situation; it is a combination of lexical units which - when used apart - stand for individual discrete concepts, and grammatical rules that serve as an instrument of combining those concepts into one complete meaningful whole reflecting objective reality through the grammatical category of tense.

2) Arbitrariness: There is no one-to-one correspondence between a linguistic form and its meaning [3, p. 5].

The idea of arbitrariness as language property was first brought up by ancient Greeks. Aristotle, for instance, stressed that there is no possible correlation between the objects signified and sounds used as their signifiers. Arbitrariness is a language property that provides for the existence of various languages through time and space as well as transference of meaning and linguistic change.

The importance of arbitrariness was largely emphasized by F. de Saussure and C. Hockett. Although he concentrated on the arbitrary nature of speech, F. de Saussure stressed that signs in writing are also arbitrary and language is not a set of predefined signifiers.

The arbitrariness principle can be applied not only to the sign, but to the whole sign-system. The fundamental arbitrariness of language is apparent from the observation that each language involves different distinctions between one signifier and another (e.g. 'tree' and 'free') and between one signified and another (e.g. 'tree' and 'bush'). The signified is clearly arbitrary if reality is perceived as a seamless continuum (which is how Saussure sees the initially undifferentiated realms of both thought and sound [2] and which makes arbitrariness yet another property of language-thought interrelation).

3) Productivity: The ability to be creative and to produce utterances not heard before [3, p.5]. It is productivity of language that enables speakers to produce an indefinite number of new utterances and understand them. Thus, human thoughts may be objectified in a variety of forms both written and spoken.

4) Cultural transmission: Language does not develop automatically if there is no culture to transmit it to the young members [3, p.5].

Culture is a set of knowledge, beliefs, customs etc. typical of members of a specific society. To be able to transmit culture, language means are divided into separate classes; each of them consists of certain words used to actualize certain experiences of life and has a general name that can be somehow applied to each word belonging to it. As experiences of different nations may be similar or vary greatly, this provides for the existence of similar and rather distinct experience classes in each language.

Therefore, the lexicon of each language includes words signifying common and peculiar to a nation objects and facts of objective reality which makes language a social phenomenon formed during a long period of time. Language is historical reflection of ancestors' experience that is manifested in language units, shared among the nation's members and common to them. Each language is a store of nation's knowledge and experience which are results of human thinking processes arbitrarily assigned to specific language units.

5) Discreteness: The sounds used in language are meaningfully distinct and discrete $[3$, p.5]. Since as a result of combination of diverse language sounds numerous words with numerous meanings may be coined, language discreteness determines another important language property: duality.

6) Duality: Distinct sounds and distinct meanings [3, p.5]. Language is a number of sounds which when used separately are meaningless phonemes; however, 
they form a meaningful whole when combined with each other. The meaning of words, which are the result of sound combination patterns, depends on types and a number of sounds used to form them. Duality is a property that helps prevent an overload of language units since a number of distinct sounds can produce an infinitely large quantity of new words.

Conclusions. Language is a set of words as basic language elements since they are somehow connected with other language units, i.e. phonemes, morphemes, phrases and sentences. Being compounds of different language sounds, words are units of dual nature, i.e. each of them has an expression plane (a set of sounds) and a content plane. The content plane of each word is a meaning which is the result of human experience and cognition processes objectified in a thought and manifested by the word.

On the one hand, each language unit is a means used to serve the purpose of objectification and manifestation of human thoughts. On the other hand, human thoughts are largely dependent on language and means used to actualize them; the combination of words (and lower-level language units that are words' component parts) helps speakers realize thoughts to the full extent and communicate them to interlocutors. Language and communication are inseparable since the former provides for thoughts' expression and the latter for thoughts' apprehension; thus, they are characterized by common properties which make both language and communication unique communication phenomena among existing animal and human systems aimed at information exchange.

\section{REFERENCES}

1. Bloomfield L. An Introduction to the Study of Language: New edition [Електронний ресурс] / Leonard Bloomfield. - John Benjamin's Publishing, 1983.383 pp. Режим доступу до pecypcy: https://books.google.com.ua/ books?id=MN3YkwOgNYC\&pg=PA16\&lpg=PA16\&dq.

2. Chandler D. Semiotics for Beginners [Електронний ресурс] / Daniel Chandler. - Режим доступу до pecypcy: http://http://visual-memory. co.uk/daniel/Documents/S4B/ sem02.html.

3. Das L. Language and Communication (Lecture notes) ГЕлектронний pecypc] / Liza Das. - IIT Guwahati, 2006. - 150p. Режим доступу до ресурсу: http://www.iitg.ernet.in/scifac/ qip/public_html/cd_cell/chapters/ lizadasqip.pdf.

4. Hockett C. The Origin of Speech [Електронний pecypc] / Charles Francis Hockett. - Scientific American 203, 1960 - pp. 88-111. Available at: http://www.illc.uva.nl/LaCo/CLAS/clc13/papers/ hockett60sciam.pdf.

5. Jespersen O. Language: Its Nature, Development and Origin [Електронний pecypc] / Otto Jespersen. Режим доступу до pecypcy: https://archive.org/ details/language itsnatur00jespiala.

6. Kurcz I. Language - Cognition - Communication [Електронний ресурс] / Ida Kurcz. - Psychology of Language and Communication. - 2001. - Vol. 5. No.1. pp. 5-16. Режим доступу до ресурсу: http://www.plc.psychologia.pl/ plc/plc/contents/fulltext/05-1_1.pdf

7. Sokolov A. Inner Speech and Thought. - Translated from the Russian edition (Moscow, 1968) by George T. Onischenko. Translation edited by Donald B. Lindsley. - Plenum, New York, 1972. - 284 pp.

8. Van der Veer, R. The Concept of Culture in Vygotsky's Thinking [Електронний ресурс] / René Van der Veer. - Culture \& Psycnology. - 1996. Vol 2. - pp. 247-263. Режим доступу до pecypcy: https://openaccess. leidenuniv.nl/bitstream/handle/1887/10285/7703112.pdf? sequence $=1$.

9. Ющук І. П. Українська мова: підручник / І. П. Ющук. -К: Либідь, 2006. -640 с. 


\section{REFERENCES}

1. Bloomfield, L. (1983). An Introduction to the Study of Language: New edition. John Benjamin's Publishing. Retrieved from: https://books.google.com.ua/books? id=MN3YkwOg NYC\&pg=PA16\&lpg=PA16\&dq

2. Chandler, D. (1999). Semiotics for Beginners. Retrieved from: http://http://visualmemory.co.uk/daniel/Documents/S4B/ sem02.html.

3. Das, L. (2006). Language and Communication (Lecture notes). IIT Guwahati. Retrieved from: http://www.iitg.ernet.in/scifac/ qip/public_html/cd_cell/chapters/ lizadasqip.pdf.

4. Hockett, C. (1960). The Origin of Speech. Scientific American, 203, 88-111.Retrieved from: http://www.illc.uva.nl/LaCo/CLAS/clc13/papers/ hockett60sciam.pdf.

5. Jespersen, O. (1922). Language: Its Nature, Development and Origin. Retrieved from: https://archive.org/ details/language itsnatur00jespiala.

6. Kurcz, I. (2001). Language - Cognition - Communication. Psychology of Language and Communication, 5, 1, 5-16. Retrieved from: http://www.plc.psychologia. pl/plc/plc/ contents/fulltext/05-1_1.pdf.

7. Sokolov, A. (1972) Inner Speech and Thought. (George T. Onischenko, Trans., Donald B. Lindsley, Trans. ed.). New York: Plenum.

8. Van der Veer, R. (1996). The Concept of Culture in Vygotsky's Thinking. Culture \& Psycnology, 2, 247-263. Retrieved from: https://openaccess.leidenuniv.nl/bitstream/handle/ 1887/10285/7703112.pdf?sequence=1.

9. Yushchuk, I. P. (2006). Ukrainska mova[The Ukrainian language]. Kyiv, Ukraine: Lybid. [in Ukrainian].

\section{Ю.О. Гайденко. Мова і думка.}

У статті розглядається проблема взаємозв'язку мови та мовлення, яка завжди становила значний інтерес для філософів та мовознавців оскільки перша - немислима без останньої, а відтак мова та думка - нероздільні. Хоча питання взаємозв'язку мови та думки вивчалося багатьма лінгвістами, загально прийнятого підходу до визначення проблеми їх взаємозалежності та взаємопроникнення не існує. Один підхід розглядає “мову як думку, а думку як мову" (М. Мюллер), а другий, що є об'єктом фокусу статті, покладається на визначення відмінностей між ними не дивлячись на те, що за цього підходу мова та думка розглядаються такими, що утворюють єдине органічне ціле. У статті розглянуто ряд статей видатних лінгвістів, що стосуються актуалізації думки. Було розглянуто та проаналізовано питання взаємозв'язків типу “мова - досвід” та "мова - культура", а також їх відношення до предмету статті. Відношення типу “мова - досвід" має неабияке значення, оскільки досвід є основою формування знань, а отже, культури та слів, що входять до складу класів мови. Оскільки кожне слово входить до певного класу мови, його значення певним чином стосується досвіду, який цей клас позначає. Назва класу також загальна та стосується всіх його складових. Накопичені знання та досвід передаються за допомогою слів: шляхом актуалізації одиницями мови. Досвід та знання повністю актуалізуються у корпусі слів тоді, коли вони сполучаються з іншими словами та формують смислові повнозначні конструкти, що перетворює мову у засіб комунікації. Оскільки комунікація може набувати вербальної та невербальної форми, вона - нерівнозначна мові. Однак, мова та комунікація володіють рядом спільних рис, описаних у статті.

Ключові слова: мова, думка, досвід, ідея, комунікація, засіб комунікації.

\section{Ю.А. Гайденко. Язык и мысль.}

В статье рассматривается проблема взаимосвязи языка и речи, которая всегда составляла значительный интерес для философов и языковедов поскольку первая - немыслима без последней, следовательно, язык и мысль - неразделимы. Хотя вопрос взаимосвязи языка и мысли изучался многими лингвистами, общепринятого подхода к определению проблемы их взаимозависимости и взаимопроникновения не существует. Один подход рассматривает «язык как мысль, а мысль как язык» (М. Мюллер), а второй, являющийся объектом фокуса статьи, полагается на определение различий между ними. Были рассмотрены и проанализированы вопросы взаимосвязей типа «язык - опыт» и «язык - культура», а также их отношение к предмету статьи. Накопленные знания и опыт передаются с помощью слов: путем актуализации единицами языка. Опыт и знания полностью актуализируются в корпусе слов тогда, когда они сочетаются с другими словами и формируют смысловые знаменательные конструкты, превращающие язык в средство коммуникации. Поскольку коммуникация может принимать вербальную и невербальную форму, она - неравнозначна языку. Однако, язык и коммуникация обладают рядом общих особенностей, описанных в статье.

Ключевые слова: речь, мысль, опыт, идея, коммуникация, средство коммуникации. 